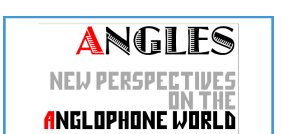

ANELOPHONE WORLI

\section{Angles}

New Perspectives on the Anglophone World

1 | 2015

Brevity is the soul of wit

\title{
Condensation and Displacement in the Poetry of Lorine Niedecker
}

\section{Axel Nesme}

\section{(2) OpenEdition}

1 Journals

\section{Electronic version}

URL: https://journals.openedition.org/angles/2058

DOI: 10.4000/angles. 2058

ISSN: 2274-2042

\section{Publisher}

Société des Anglicistes de l'Enseignement Supérieur

\section{Electronic reference}

Axel Nesme, "Condensation and Displacement in the Poetry of Lorine Niedecker", Angles [Online], 1। 2015, Online since 01 November 2015, connection on 09 June 2022. URL: http:// journals.openedition.org/angles/2058 ; DOI: https://doi.org/10.4000/angles.2058

This text was automatically generated on 9 June 2022.

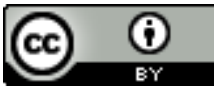

Angles est mise à disposition selon les termes de la Licence Creative Commons Attribution 4.0 International. 


\title{
Condensation and Displacement in the Poetry of Lorine Niedecker
}

\author{
Axel Nesme
}

In his essay on Wit and its Relation to the Unconscious, Freud shows that "condensation, displacement, and indirect representation" (750) are the three features shared by dreams and the operations of wit. To the extent that condensation, like metaphor, brings together items located within the same paradigm while displacement, like metonymy, proceeds by lateral moves involving elements contiguous to one another, the operations of the unconscious and the workings of wit are structurally cognate to the poetic function which "projects the principle of equivalence from the axis of selection into the axis of combination" (Jakobson 71). In other words, the vertical order of the paradigm, along which the unconscious phenomena of condensation take place, contaminates the metonymic linearity of the speech chain so that, regardless of syntax, metonymic connections are established on the sole basis of paradigmatic parallelisms. In this paper I wish to explore the work of an American poet which often hinges on those mechanisms. To Lorine Niedecker, compression was an aesthetic imperative that translated into witticisms analogous to those Freud studies in his essay, but also determined her preference for formal and thematic compactness: Niedecker's short lines, rarely exceeding four or five preferably mono- or disyllabic words, her syntactical ellipses, her distrust of "city talk" (CW 222), ${ }^{1}$ consistent with her admiration for the late Stoic philosopher Marcus Aurelius, often match observations reduced to bare facts linked by the smallest possible number of connectives. We will see that by making the pleasure of the text contingent on such principles of strict poetic economy, Niedecker also positions herself vis-à-vis the immediate historical and political context of her day, and that the anti-essentialist stance implicit in her cultivation of conciseness also leads to a questioning of gender roles and of the agon that binary logic inevitably entails. 
2 The best introduction to Niedecker's poetics of reticence may be found in her 1962

"Poet's work":

Grandfather

advised me:

learn a trade

I learned

to sit at desk

and condense

No layoff

from this

condensery ( CW 194)

3 As readers of The Prelude will probably agree, this text is as concise a poetic autobiography as they come. Determining how it enacts the aesthetic precept derived from the injunction of the speaker's grandfather may, however, require more space than it takes to formulate it in these three provocatively terse tercets. At first sight, the line "to sit at desk" located at the exact halfway point of the text, offers the most straightforward illustration of how Niedecker intends to practice her art with the omission of the superfluous definite article which has been removed like water from cow's milk in an ordinary condensery, thus showing how proficient the poet has become in her trade, doubtful as it may be that this was the kind of vocation that her grandfather had in mind.

It is, however, in the problematic connection between the verb "condense" and the noun "condensery" as mediated by the deictic that the poem's chief interest lies. Being laid off from a factory means that one will no longer have a job in that particular location and will have to seek employment elsewhere. A condensery, in other words, is a place. Learning to "sit at desk / and condense," on the other hand, is learning to perform an activity. One does not get laid off an activity per se: one gets laid off from the place where it is performed. The deictic "this," therefore, is a syntactical shortcut that imperceptibly shifts the focus of the poem toward the minute difference between verb and noun, a difference that is contingent on our reading of the suffix -ery. This suffix, according to Webster's International Dictionary, may designate 1) "qualities collectively," as in "snobbery;" 2) an "art, practice" or "trade," as in "mountebankery"; and 3) a "place of doing, keeping, growing, breeding, selling," as in "fishery," 4) a "collection," as in "greenery," and 5) a "state" or "condition," as in "slavery." By interposing "this" between verb and noun, Niedecker thus dislodges meaning 3) from its rightful place to the benefit of meanings 2) and 5), turning a common noun designating a place into one which now defines that activity and condition which is poetic "condensery." In other words, by means of this poetic intervention on the signifier combining displacement and condensation, the two mechanisms involved in the production of wit according to Freud, Niedecker has redefined a word which now uniquely identifies her aesthetic without subtracting it from common usage, let alone coining a new term. In the mere interval separating "condense" from "condensery," she has thus compressed a philosophy of linguistic commonality ${ }^{2}$ which some of her lengthier prose writings reveal as a continuation of the belief that the same common materials circulate between all parts of the phenomenal world:

The journey of the rock never ends. In every tiny part of any living thing are materials that once were rock that turned to soil. These minerals are drawn out of the soil by plant roots and the plant used them to build leaves, stems, flowers and fruits. Plants are eaten by animals. In our blood is iron from plants that draw it out 
of the soil. Your teeth and bones were once coral. The water you drink has been in the clouds over the mountains of Asia and waterfalls of Africa. The air you breathe has swirled through places of the earth that no one has ever seen. Every bit of you is a bit of the earth and has been on many strange and wonderful journeys over countless millions of years. (Lake Superior 7)

In a footnote about North Central, the collection derived from the travelogue from which this quote is taken, Jenny Pennberthy points out that Niedecker's "notes for the poem [...] include detailed research into the history and geology of the [Lake Superior] region" ( $\mathrm{CW}$, note p. 434). This is particularly relevant to Lake Superior, the first section of North Central, where Niedecker systematically conflates geological and historical time, interweaving personal anecdotes, fragments from the history of the early exploration of the Lake Superior region, and observations on the area's geology, repeatedly casting human time against the backdrop of the aeon-old permanence of rocks and of the mineral particles of which they are made up. The central analogy here is between the telluric forces that shaped rocks and mountain formations, and the poem's own specific energy which contains-condenses those various dimensions within the compressed limits of the book:

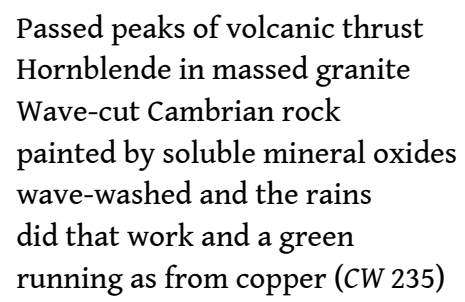

6 The same phenomenon of compression, Niedecker suggests, may be discerned within the narrower confines of a single human life, as in "Radisson" (CW 232) where a short physical portrait of the explorer, a brief quote from his description of the region as a "laborinth of pleasure" and the episode of his torture by Mohawks are contained within six lines that do not even contain a single conjugated verb.

One of the most successful examples of Niedecker's condensery work is the autobiographical "My Life by Water" ( $C W$ 236-7) where the incoming spring is troped as a boat approaching the speaker's house on Blackhawk Island:

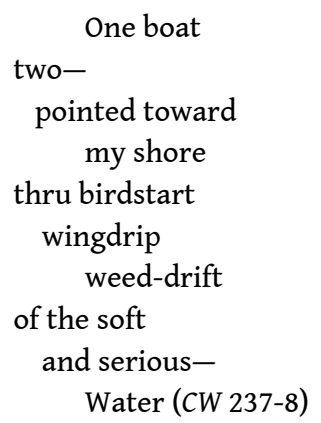

The contents and the form of these lines are virtually indistinguishable. As the two boats point toward the speaker's shore, so, thanks to the artifice of lineation, each tercet points toward its final line and the poem as a whole is directed towards the unexpected noun of which the adjectives "soft" and "serious" are predicated, namely "Water," set apart from the rest of the syntax by the dash in the penultimate line. Similarly, in the compounds "wingdrip" and "weed-drift" phonemes themselves seem to have been set adrift: the repeated short [i] of "wingdrip" briefly expands into the long [I:] of "weed," then once again contracts into the short [i] of "-drift." As for the 
signifieds themselves, they are barely more than after-thoughts generated in the wake of the phonic transformations that occur at the surface of the poem and/or of the "water." Some kind of metonymic continuity may indeed be projected onto the "Birdstart / wingdrip / weed-drift" ternary: fragmentary as those notations seem, they follow the logic of cause and effect which contains seeds of-albeit minimalnarrativity: as the bird startled by the approaching boat takes off, a few drops drip off its wings, and the motion of the weeds ensues from what small ripples the bird causes at the surface of the lake as it flies away. Yet such narrativization of Niedecker's lines is not merely artificial, but also markedly at odds with the poetic project underlying her formal choices. The compound nouns under examination are precisely intended to bypass the requirements of narrative syntax, to offer an alternative to the prodigal economy of prose by condensing processes within the limits of coined substantives which do not negate them but reduce them to their bare perceptual rudiments, to a set of discontinuous sensory data which may or may not be woven into stories.

In his seminal book on Literature and the Phonotext Garrett Stewart has shown how seemingly fortuitous phenomena of phonemic adhesiveness between words are likely to generate poetic semiosis. Niedecker's "Weed-drift" is a case in point. Since adjacent terminal and initial consonants are not differentiated in ordinary pronunciation, the phonetic transcription of the word would read as [wI:drift]. The intermediary [d] thus drifts back and forth across the boundary between the two words that the hyphen makes clearly visible, since contrary to the two previous compounds, "birdstart / wingdrip," the stitches are still visible: condensery is a form of verbal surgery which does not erase all traces of its operations, thus clearly indicating that juxtaposing compound nouns and doing away with the linearity of syntactical relations does not rhyme with essentialization. As we have just seen, one may read cause-effect relations into Niedecker's compounds, but in doing so, one also misses the point that her poetry's main focus in on what Deleuze called "effects [which] are not bodies, but, properly speaking, 'incorporeal' entities. [...] not physical qualities and properties, but rather logical or dialectical attributes [...,] not things or facts, but events" (4-5). Leaving the stitches visible, as Niedecker does in "weed-drift," means emphasizing that, in Deleuze's quote of Emile Bréhier's "reconstruction of Stoic thought [..., 'when the [poet's] '“scalpel cuts through the flesh' [of words,] the first body produces upon the second not a new property but a new attribute, that of being cut. [...] This way of being finds itself somehow at the limit, at the surface of being." Such "incorporeal events [...] play only on the surface, like a mist over the prairie," one might as well say: on the surface of a lake as of the poem entitled "My Life by Water." They occur at the juncture between experience and text. Indeed they pose such a challenge to essentialist thought that they make words and things no longer separate identities, but overlapping spaces where trochaic rhythms fall like water drops-five of the poem's last six lines end in trochees-and whispering sibilants ("soft / and serious") merge their sound with the murmur of the water set in contrast with the sonorous plosives and dentals that resonate in the very lines thematizing the phenomena which temporarily disrupt its surface.

10 We have seen earlier how Niedecker's choice of the word "condensery" to define her poetic practice involved a small morphological displacement while acknowledging that the word itself remained the shared property of a linguistic community. Consistently with the politics underlying this gesture, some of the noun combinations manufactured 
in Niedecker's poetic condensery provide alternatives to what might be their counterparts in capitalist economy. ${ }^{3}$ Thus, in "TV" (CW 239) compound interest and the "compound eye / of the insect" also define the poet's own interest in, and eye for, the subject she observes: "the wave-line / on shell, sand, wall / and forehead of the one who speaks" ( $C W$ 239), as it runs through separate identities, proclaims them to be continuous, compatible with seriality while preserving a degree of uniqueness reminiscent of the paradox of discrete series that George Oppen explored in of Being Numerous. As the adjective "compound" may alternately describe the abstract selfperpetuating mechanism at the heart of the capitalist machine as well as that minute particular of the concrete world which is the multifaceted eye of a fly, the poem also defines itself as a compound of sorts. Within its confines (one of the meanings of "compound") words (the signifier, "compound") are brought together, and what interest the poem accrues involves a non-predatory way of capitalizing on polysemy as well as, in this particular instance, intertextuality.

11 In her biography of Niedecker, Margot Peters quotes Niedecker telling Zukofsky: "I've had two revolutions in my life, [...] one when I first laid eyes on your writing and two when I read Shakespeare's Sonnets" (loc. 1254). The Shakespearian echo is hard to miss in " $T V$ " where, regardless of the exact contents of the documentary that may have inspired the poem, all we need to do to understand the second quatrain is to carry polysemy to its logical end. Since the same adjective, "compound," may refer to capital gain or the eye of an insect, and since the signifier "line" may just as well describe the pattern on "shell, sand, wall /" as the wrinkles on the "forehead of the one / who speaks," we need to ask ourselves if the line that connects the shell and the speaker's forehead does not reach beyond the limits of Niedecker's poem, referring also to the discrete series of lines of which a poem is compounded, and beyond that, pertaining to the poem's own line of ascent, one that reaches all the way back to the sonnets where Shakespeare puns on the multiple meanings of the word "line." The line on the forehead "of the one / who speaks" is thus also the line in the poem of the one who writes in the manner of Shakespeare implicitly contrasting the "eternal lines" of Sonnet 18 with those that will eventually grow on the young man's forehead. Niedecker's poem thus designates itself as a variety of compound interest generated by the laws, not of market, but of literary economy where securing intertextual profit requires acknowledging a proportionate degree of symbolic indebtedness.

In Freud's discussion of wit, some of condensation's most successful offshoots are coinages like the portmanteau words "famillionnaire" (639) and "alcoholidays" (642). As we saw earlier in "Poet's Work," Niedecker's version of condensery more frequently involves eliminating superfluous parts of speech and observing what poetic effects such ellipses may generate. Some of those turn out to be fairly witty, as can be judged by this quatrain:

The boy tossed the news

and missed

They found it

on the bush (CW 217)

Much as Niedecker may have disliked the comparison, not only does this poem, by truncating the word "newspaper," achieve a degree of compactness only matched by 
Emily Dickinson ${ }^{4}$, but it also brings to mind Dickinson's conflation of the eternal and the temporal in lines such as these:

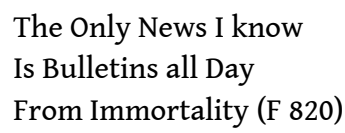

14 The immediate effect of Niedecker's poem, however, is one of amused surprise at the absurd notion that news can be found on a bush. This logical impossibility is, of course, easily resolved by supplementing the missing half of the word on which meaning temporarily stumbles. The reader, in other words, goes through "confusion and clearness" ["Verblüffung und Erleuchtung"], the two stages involved in the reception of a witticism mentioned by Freud in his introduction to Wit and Its Relation to the Unconscious. Where Niedecker's poem rises above the level of the witticisms listed in Freud's essay, however, is that it also names the origin of its own success as a fragment of poetic wit. What is a-miss-and therefore a proportional semiotic gain-in Niedecker's line is itself the mirror image of the newspaper boy's faulty gesture and its correction. The principle of economy by which wit always abides (Freud 653), as does the unconscious mechanism of condensation (Freud 752), thus impacts the mise en abyme of the boy's initial mistake now reflected in the poet's own felix culpa. Within the anecdote as within its poetic rendition, losses are counterbalanced by equal gains, an observation which also applies transversally to the way the contents of the anecdote and its witty retelling interrelate, since one boy's miss proves another (poet)'s hit.

Several of the puns that Freud describes in his discussion of wit by condensation revolve around the trope of syllepsis, in which the same word is used in two unrelated meanings as in the phrase Freud quotes in the original French: "c'est le premier vol de l'aigle" (650). In Freud's example, the immediate and the historical context are instantly accessible to the listener, whose enjoyment is a function of his being able to toggle back and forth between the signifieds "flight" and "theft." In the following poem by Niedecker, displacement and condensation are combined in such a way that the former creates a diversion from the latter. In other words, it is displacement to the second power, involving both the phonemic makeup of the signifier and the very dynamics of reading where attention itself shifts between the syntagmatic and paradigmatic axes:

The slip of a girl-announcer:

Now we hear

Baxtacota in D minor

Played by a boy who's terrific.

This saxy Age.

Bach, you see, is in Dakota

But don't belittle her,

She'll take where you want to go ta. (CW 152)

We understand here what Freud meant when he described wit as double-sided or "double-dealing" (756), referring to how easily it maintains inhibition by preserving "sense in nonsense" (756). In Niedecker's poem, voice plays a central role in keeping wit within socially admissible limits by shifting the focus away from the poem's wording toward its specific music. The girl-announcer's slip is presumably rendered verbatim in the first quatrain, affords the speaker a chance to display her skills as a ventriloquist in the second quatrain, where she mocks the traces of Norwegian and Swedish influence that may still be detected in upper-Midwest American English. While Niedecker acknowledges that the woman's accent may be "saxy"-thus mitigating the 
reference to sex with an allusion to the sound of the saxophone-, her primary interest clearly lies with the distortions that the somewhat unsophisticated girl-announcer inflicts on various vowels, beginning with her mispronunciation of Bach's Toccata in D minor which yields the comical neologism "Baxtacota." That this linguistic nugget does not deserve to be belittled anymore than its unwitting author is confirmed by the fact that, like the girl-announcer, it will "take where you want to go ta," as Niedecker demonstrates, by letting the coinage guide her rhyme choice toward the name of the state where the woman's accent is most likely to be encountered. Yet whatever pleasure one may derive from this fragment of linguistic local color verging on doggerel is only a thin veil covering what may have been, at the time (1952), the slightly less universally acceptable reality of sex.

In the second quatrain, Niedecker clearly implies that the announcer simultaneously distorted the title of a musical piece-notably by inverting vowel sounds-as well as the rules of genteel musical appreciation by showing herself also possibly interested in the musician's good looks, the all-encompassing adjective "terrific" being vague enough to suggest that her enthusiasm stretches beyond the quality of the artist's performance. This is why Niedecker marvels at a modern age when a musician's physical appearance seems to matter more than his actual talent, and mildly denounces this inappropriate change of focus by throwing a saxophone into the midst of baroque harmonies. Yet the girl-announcer's misplaced-if not displaced-sense of priorities only adds insult to injury, since even before her erroneously shifting the emphasis from the musical to the physical, a shift had already made itself visible, at least if one bears in mind that the word "shift" means a change-or a slip. In a "saxy Age," a girl-announcer's "slip" (of the tongue) betraying her attraction to the musician she is presenting temporarily reveals what the code of conventional discourse and the rules of fashion demand should remain hidden; and as it turns out, it did so, even before the contents of her mischaracterization were actually formulated. Indeed, once we understand that the announcer's slip consisted in an expression of desire, then the double meaning of the word "slip" as referring to a woman's undergarment is activated retroactively and makes us realize that the poem's first line contained a pun. Through the workings of Niedecker's witty condensery, and in keeping with the Deleuzian logic described earlier, the slip that is the object of exposure and the slip that exposes it, have thus become strictly identical.

18 Although the manifestations of wit analyzed by Freud are often humorous and equivalents of those that may occasionally be found in Niedecker's poetry, wit obviously does not limit itself to more or less tendentious double-entendres, nor do all products of Niedecker's "condensery" show the playfulness of "The slip of a Girl Announcer." In what follows, I want to examine poems where Niedecker's wit is brought to bear on the historical context of the Cold War to which several of her poems refer quite explicitly, beginning with an early version of a 1964 text contained in the selection of poems Cid Corman edited under the title, The Granite Pail, where Niedecker attempts a modern equivalent of metaphysical conceit, as defined by Samuel Johnson and quoted by T.S. Eliot in "The Metaphysical Poets" (60). Indeed, the surprising juxtaposition around which Niedecker's short poem, "The Radio Talk," revolves is not 
unlikely to convey the impression that "the most heterogeneous ideas are yoked by violence together":

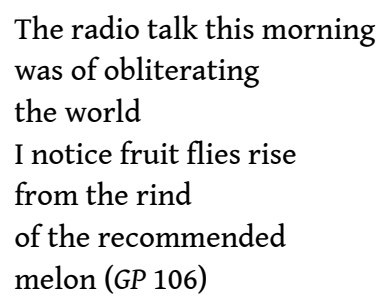

Here the vision of nuclear holocaust conjured up in the first three lines is translated and toned down in the form of the more familiar, hence more "cheerful" mention of the fruit flies rising "from the rind / of the recommended / melon." The placement of the words "world" and "melon" at the close of each of the poem's two short sections confirms the fairly obvious analogy between the round shape of the terrestrial globe and of the fruit the speaker has just purchased. The rising fruit flies, already suggestive of the narrow limit between ripeness and decay, become retroactively readable as small-scale equivalents of a nuclear bomb's mushroom cloud. Niedecker's poem, however, is equally preoccupied with the destiny of letters and the possibility of their utter erasure, since etymologically, the verb, "obliterating / the world" means removing it from existence as one strikes out letters or words. Less figuratively perhaps, detonating a nuclear device means unleashing a chain reaction whose destructive potential is the subject of the "radio talk" to which the poet responds by including the signifier of the end within the seemingly innocuous word "recommended"; but also, more interestingly, by setting in motion another chain reaction of sorts, namely, in the second half of the text, the concatenation of sounds that connect the words "flies," "rise," "rind," "recommended," and "melon" as follows [flaiz]-[raiz] / [raiz]-[raind] / [raind]-[rekəmendəd] / [rekəmendəd]-[melən]. Like many of the witticisms studied by Freud, the poem thus hinges on an implicit pun on the phrase "chain reaction." In "The Radio Talk," however, the trope is not actualized. It functions instead as the poem's semiotic matrix defined by Michael Riffaterre as merely "hypothetical, being only the grammatical and lexical actualization of a structure" so that "the text functions something like a neurosis: as the matrix is repressed, the displacement produces variants all through the text, just as suppressed symptoms break out somewhere else in the body" (19). Yet, by displacing this chain reaction towards the scene of writing, Niedecker does not reduce her poem to a mere symptom of its time and place, powerlessly mimetic of the physics of nuclear fission: she also suggests that the same mechanism may be turned against itself in order to serve the purposes of literary creation instead of literal destruction. As will be seen below, this is a recurrent device in Niedecker's art of condensery.

During a trip through Lake Superior country Niedecker took with her husband Al in 1966, she wrote a number of notes pertaining to the history and geology of the region, some of which I quoted earlier. Of particular interest to her was the work of Henry Rowe Schoolcraft, who, in Niedecker's own account, "was Indian Agent of the Territory, a geologist and something of a poet, a politician and an explorer" (Lake Superior 14). It was Schoolcraft who, in 1832, located the source of the Mississippi in a lake in north central Minnesota. Although the Indian name of the lake was "Elk Lake," Schoolcraft renamed it "Lake Itasca," and that is how this body of water has been known to this day. Although the name sounds native American, it actually has little in common with 
Omashkoozo-zaaga'igan, its original Ojibwe name meaning "Elk Lake." Instead, Niedecker notes that Schoolcraft "took the letters of [the] word [Itasca] from the Latin veritas caput, meaning true source" (Lake Superior 23). As it turns out, Schoolcraft frequently coined such native-American sounding names. wonder if the literary kinship she felt with Schoolcraft was not partially due to his somewhat idiosyncratic notion of what defines a true name. Indeed, there are many ironies involved in the anecdote Niedecker transcribed in her travel notes. First, there is the fact that veritas caput is a solecism, since veritas is a feminine noun, and the Latin word caput, being neutral, should be preceded by the adjective verum. The only way "veritas caput" could hold as a genuine Latin phrase would require analyzing it not as a noun phrase but as a complete sentence from which the verb has been omitted: veritas caput (est), truth is the source. In that case the paradoxical implication would be that truth is the source-of all false etymologies. There is also the odd observation that those Latin words mistakenly believed to mean "true source" by Schoolcraft himself, were both truncated and pasted together in order to produce the spurious Indian name (ver-Itasca(put). The signifier of the one true indivisible source (of the Mississippi) was thus obtained by cutting into the fabric of words whose signifiers designate that which cannot be divided from itself (truth-as-one) or from its body (the head). Finally, "Itasca" is an imitation substituted for the original, a deliberate linguistic sleight-ofhand whereby, at the very moment of his actual discovery of the source, Schoolcraft himself exposed origin per se to be an ex-post-facto mythical construct, inevitably caught in a process of its own erasure, and truth to be not a cause or source, but an effect entirely contingent, not on reality, but on the realism of an otherwise fictitiously original name. We understand, therefore, why Niedecker depicted the Lake Superior regions as the stage of a large-scale linguistic vanitas where the corruption which is structurally inherent in language becomes visible:

I think our NW (Lake Superior region, Minn., Mich., Wis.) is not only for the geologist, a massive, grand corruption of nature. And of language (wonder if Bosho is still used in speech for Bon jour! Indian, French, British-. The Northwest passage to the Orient has its Bosho only like a ton of rock. And weak verse like Longfellow's Hiawatha. But some kind of poetry has been felt by several of the geologists in that region. (Lake Superior 51)

In Wit and Its Relation to the Unconscious, Freud observes that wit requires the agency of a third party who, by acknowledging it as such, gives it currency: "only that is a witticism which I allow to count as a witticism" ["nur das ein Witz ist, was ich als einen Witz gelten lasse"]. The concept of the symbolic Other explored by Lacan, notably in his Seminar on The Formations of the Unconscious, expands on this insight by grouping under the same heading the Other of the linguistic code, whose law is breached or at the very least exposed in the production of a witticism, and the Other listener for whose benefit that witticism is uttered. In other words, wit is produced by a speaker playing with the rules of ordinary discourse at the expense of a third party, and for the enjoyment of a listener. Niedecker's "Could you be right" (CW 129) is a case in point I want to examine for two complementary reasons. First, because here again, the poet addresses the possibility of nuclear obliteration and answers that threat with her own strategy of verbal displacement. Secondly, because of the insight it yields in light of the above analysis of the poet's notes on the Lake Superior region where, as we have just seen, the symbolic code is repeatedly invoked and transgressed. What this poem shows is that it 
is where language is held up as the repository of original truth-or, more precisely, of the truth about origins-that it proves to be at its most mendacious, so that what guarantees are sought from this symbolic Other, it not only fails to provide, but also exhibits instead the fault at its very core.

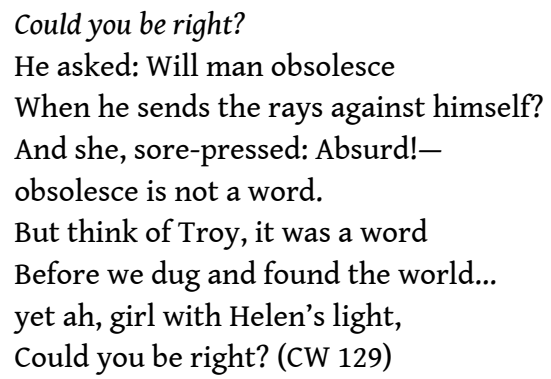

The biographical occasion behind this fictitious dialogue is a situation where the roles were actually reversed. In Niedecker and the Correspondence with Zukofsky 1931-1970, Jenny Penberthy writes that the poem stems from a discussion between Niedecker and Zukofsky in which Niedecker was the one who used the verb in a draft, and Zukofsky "had evidently questioned her use of "obsolesce" (9-10). The first quatrain is a good illustration of those witticisms that Freud placed under the rubric of "displacement wit" (661). Whereas the man contemplates the possibility that mankind might make itself obsolescent through nuclear self-destruction, the woman displaces the semantic stress of his query from the level of the signified to that of the signifier. Displacement thus occurs both in the interval between the poem and its occasion-since the genders have been reversed- and within the first quatrain. In light of Freud's hypothesis that "as we know that displacements in dream-work point to the influence of censorship of conscious thought, we will consequently be inclined to assume that an inhibiting force also plays a part in the formation of wit when we find the process of displacement among the techniques of wit" (754), one may reasonably assume that in the scenario that plays out in Niedecker's poem, Zukofsky's own superegoic censorship is being circumvented.

What pleasure may be derived from the female speaker's "faulty thinking" (Freud 666), however, extends beyond merely identifying the nature of her misprision. The absurdity of the woman's response is indeed compounded by the wording she adopts to dismiss the man's question: by calling his query absurd, she mostly draws attention to the preposterousness of her own reaction. Where the first speaker's question located the issue of self-destruction in the real, the second speaker twice displaces it onto the symbolic plane: first, by asking whether the word "obsolesce" actually exists in the English language, then, by using a word which causes her own statement to selfdestruct. As in "The Radio Talk," these various displacements along the metonymic chain are a chain reaction that plays out within the enclosed space of the poem's first quatrain which, perhaps in the manner of the imploding detonating device used to trigger the first atomic bombs at the end of World War II, collapses upon itself, not simply because the exclamation "Absurd!" designates itself in the very act of targeting the utterance that precedes it, but also because the whole conversation is based on the erroneous premise that "obsolesce is not a word," even though the OED dates the first occurrence of the verb to the year 1873.

Staged as a verbal confrontation between a male and a female poet where Niedecker may conceivably have acted out her own ambivalent relationship to Zukofsky, the 
poem is primarily at war with itself. Like mankind in possession of nuclear devices, it contains the seeds of its own obliteration, which may explain why the second quatrain shifts the conversation towards the subject of the Trojan war. From the male speaker's purely factual perspective, of course, the reference is suggested by the observation that entire nations may be erased from the surface of the earth as was Troy, which survived only as a name of legend until the archeological site of the city was finally located in 1871. The reference, nonetheless, may also offer a reflection-and tentative resolution -of the poem's inner agon. Indeed, not only does Niedecker's text have its own Trojan horse in the guise of the word "Absurd!" which, as I have tried to show, undermines its first quatrain from within: the enigmatic question heard in the last two lines suggests a parallel between the female speaker and Helen of Troy that challenges the binary oppositional logic out of which wars are born.

According to certain legends, Helen of Troy knew about the Trojan horse. She helped Odysseus enter Troy to steal the Palladion, a sacred statue of the Greek goddess Pallas Athene, and on the night when Troy was taken, she waved a light from the ramparts of the citadel in order to signal to the Greeks that they could enter the city. Niedecker's sibylline question to the "girl with Helen's light, / could you be right?", therefore, may be a prefiguration of the poet's focus, in North Central (1968), on those "minerals of the rock" which transcend all man-made distinctions, national borders included:

Iron the common element of earth

in rocks and freighters

Sault Sainte Marie-big boats

coal-black and iron-ore-red

topped with what white castlework

The waters working together

internationally

Gulls playing both sides (CW 232)

In light of "Could You Be Right," it becomes clear that girls too may occasionally "[play] both sides" as the Trojan Helen did, waving her light to let the enemy in. The "girl with Helen's light" may thus be doubly "right," first, in exercising poetic wit so as to answer her male counterpart's question absurdly by translating into purely poetic terms; second, by making it virtually impossible for the poem to achieve any degree of finality or self-consistency, all the more so since the voice that takes over in the last two lines cannot unequivocally be traced to either protagonist of the verbal exchange, and in any event, falls short of adopting a position that would settle the debate, since it merely deflects it by giving the last word-to a question.

The conclusion that may be drawn from this joint analysis of "Could You Be Right" and "Radio Talk" is that, in both instances, Niedecker does not so much register the fear of "the grand blow-up- / the bomb" (CW 253-4) that haunted the generations of the Cold War era, as displace the fear inside the narrow frame of her poetic condensery where negotiations become possible with the law in its various avatars: first, the law that manifests itself through the linguistic rules that govern the formation of words, since one person's hapax is another's ordinary currency, and the limits of the sayable may always be pushed back, as witnessed, in the history of English, by the growing number of inceptive verbs derived from Latinate adjectives ending in -escent; secondly, the more stringent imperative of finiteness, which the threat of nuclear disaster materializes and which is indissociable from the limits set to desire by language itself, limits which are temporarily lifted during the brief interval where poetic wit is given 
free rein, and during which the possibility of human demand being satisfied without any remainder is glimpsed. Lacan describes this effect of wit in the following terms:

le mot d'esprit consiste en ceci qu'il se passe quelque chose dans l'Autre qui symbolise ce que l'on pourrait appeler la condition nécessaire à toute satisfaction. A savoir que vous êtes entendu au-delà de ce que vous dites. En aucun cas en effet, ce que vous dites ne peut vraiment vous faire entendre. [...]

Ce qui, dans le trait d'esprit, supplée, au point de me donner une sorte de bonheur, à l'échec de la communication du désir par la voie du signifiant, se réalise de la façon suivante - l'Autre entérine un message comme achoppé, échoué, et dans cet achoppement même reconnaît la dimension au delà dans laquelle se situe le vrai désir, c'est-à-dire ce qui, en raison du signifiant, n'arrive pas à être signifié. (Lacan 150)

In the exercise of poetic wit, therefore, that which, of desire, fails to be signified appears, nonetheless, answerable to and, conversely, the enigma of the Other's answerability for the speaking subject, and the question of the Other's ability to guarantee the subject's utterance, is also held in abeyance, if not solved. All of which takes us back to Niedecker's notes on Schoolcraft. I pointed out earlier that the poet's account of the historical circumstances surrounding the discovery of the source of the Mississippi conveys the disturbing message that any 'true source' is spurious. In Lacan's theory, this problem is couched in terms of a void at the heart of the symbolic order, the lack of a signifier capable of adequately vouching for the subject's place in the Other of language: a signifier which, in the same way as identifying and naming the true source of a river is deemed to satisfactorily settle the question of its origin and allow the explorer to trace its complete trajectory from that point onward, would adequately name and locate in the signifying chain the subject's origin and thus contain the final word regarding his/her being and desire. That void, as we have seen, is what Niedecker's short poems briefly contain and conceal.

\section{BIBLIOGRAPHY}

Blau DuPlessis, Rachel. Blue Studios: Poetry and Its Cultural Work. Tuscaloosa: U. of Alabama P., 2006.

Deleuze, Gilles. The Logic of Sense. Trans. Mark Lester. Ed. Constantin V. Boundas. New York: Columbia UP, 1990.

Dickinson, Emily. The Poems of Emily Dickinson. Ed. R.W. Franklin. Harvard: Harvard UP, 1999.

Eliot, T.S. “The Metaphysical Poets." Selected Prose of T.S. Eliot. Ed. Frank Kermode. New York: Harcourt Brace, Jovanovitch, 1975. 59-67.

Freud, Sigmund. Wit and its Relation to the Unconscious. Trans. A.A. Brill. The Basic Writings of Sigmund Freud. New York: The Modern Library, 1966. 633-803.

Jakobson, Roman. "Linguistics and Poetics." Language and Literature. Ed. Krystyna Pomorska and Stephen Rudy. Cambridge, MA. \& London: Harvard UP, 1987. 62-94.

Lacan, Jacques. Les Formations de l'inconscient. Paris: Seuil, 1998. 
Middleton, Peter. “Niedecker's Folk Base.” The Objectivist Nexus: Essays in Cultural Poetics. Ed. Rachel Blau DuPlessis and Peter Quatermain. Tuscaloosa and London: U. of Alabama P., 1999. 160-188.

Niedecker, Lorine. Collected Works. Ed. Jenny Penberthy. Berkeley, Los Angeles, London: U. of California P., 2002.

Niedecker, Lorine. Lake Superior. Seattle and New York: Wave Books, 2013.

Niedecker, Lorine. The Granite Pail. Ed. Cid Corman. Frankfort, KY: Gnomon Press, 1996.

Penberthy, Jenny. Niedecker and the Correspondence with Zukofsky 1931-1970. Cambridge: Cambridge UP, 1993.

Riffaterre, Michael. Semiotics of Poetry. London: Methuen, 1980.

Oppen, George. Of Being Numerous. New Collected Poems. Ed. Michael Davidson. New York: New Directions, 2002. 161-208.

Peters, Margot. Lorine Niedecker: A Poet's Life. Madison: U. of Wisconsin P., 2011. Kindle edition.

\section{NOTES}

1. CW: Collected Works.

2. Niedecker was always eager not to dissociate her diction from the speech patterns of ordinary Americans, which occasionally set her apart from some of the Objectivists with whom she came into contact through friendship with the communist poet Louis Zukofsky. Peter Middleton emphasizes her "resistances to appropriation" (186), and points out that "placing everyday folk speech in poetry was something [...] that divided Niedecker from [George] Oppen. Her momentary impatience with Oppen may also have had roots in her awareness of his criticism of poets who attempted to 'reproduce common speech' in poetry. Such practices smacked of suspect 'populism' to Oppen" (Middleton 170).

3. Rachel Blau DuPlessis stresses that "anonymity for Niedecker may be construed in both gender and class terms. She always accepted herself as a populist, a member of the populace, the vox populi" (Blau DuPlessis 144).

4. According to Margot Peters, "fellow workers knew Lorine wrote poetry, said Edwin Honig, and 'kidded her about being another Emily Dickinson, but she brushed this aside."' (loc. 802)

\section{ABSTRACTS}

In this essay I explore the manifestations of condensation and displacement, the two major mechanisms identified by Freud in his study on Wit and Its Relation to the Unconscious, throughout the poetry of Lorine Niedecker. I begin by examining the implications of Niedecker's definition of her poetics as an art of "condensery," starting with her idiosyncratic handling of the suffix, a mere distortion of common usage that remains compatible with language being a matter of joint ownership. Phenomena of condensation are also at work in the changes that Niedecker observes in the rock formations of the Lake Superior region and records in North Central, conflating 
geological and human time, and translating those processes into compound nouns which, though they seemingly erase linear syntactical relations, do not serve essentializing purposes, reducing instead the distance between words and things in the manner of Deleuzian incorporeal events. Following the same logic, punning on the word "compound" allows Niedecker to draw the lineaments of a non-capitalist intertextual economy in which symbolic interest is generated by borrowing, notably from Shakespeare's own metapoetic puns. Such plays on words are where Niedecker's art of condensation comes closest to Freud's analysis of wit. Indeed, some of her poems involve semantic shortcuts or humorous double-entendres analogous to those described by Freud, while consistent with the above mentioned logic of the event. Niedecker's technique is most reminiscent of metaphysical conceit, however, when she tackles the immediate historical context of the Cold War. Poetic "condensery," in this particular instance, proves instrumental in displacing human conflict towards the scene of the textual agon. I suggest that the poet's handling of displacement in her poems on the threat of nuclear "obliteration" also allows her to settle gendered literary disputes between Niedecker and Zukokfsky, and thereby question the agency of the Lacanian symbolic Other who, as it is called upon to authorize or invalidate certain lexical choices, also exposes its own failure to guarantee the subject's utterances and being.

Il s'agit dans cette étude d'explorer, dans l'œuvre poétique de Lorine Niedecker, les manifestations des mécanismes de condensation et de déplacement que Freud place au centre de son étude sur Le Trait d'esprit et sa relation à l'inconscient. La poésie de Niedecker, placée sous le signe de la « condenserie ", investit tout d'abord le traitement singulier du suffixe qui est partie intégrante de ce terme dont Niedecker modifie l'usage ordinaire tout en restant dans les limites d'une conception de la langue comme propriété partagée. La condensation est également à l'œuvre dans les transformations que Niedecker observe dans les roches de la région du Lac Supérieur et dont elle dresse le registre dans le recueil North Central confondant temporalités géologique et humaine, et traduisant ces processus sous forme de noms composés qui, quoiqu'ils semblent effacer les relations syntaxiques dans leur linéarité, ne sont pas pour autant subordonnés à une visée essentialiste, mais œuvrent à réduire l'écart entre les mots et les choses à la manière de l'événement incorporel évoqué par Deleuze. Dans la même logique, en jouant sur le double sens du mot "compound", Niedecker esquisse les contours d'une économie intertextuelle non capitaliste dans laquelle l'emprunt est générateur de gain symbolique, notamment lorsqu'il porte sur les jeux de mots métapoétiques shakespeariens. C'est dans ces dispositifs que l'art niedeckerien de la condensation s'approche au plus près du trait d'esprit analysé par Freud, certains poèmes opérant raccourcis sémantiques ou double-entendres semblables à ceux qu'évoque Freud, même s'ils relèvent en dernière analyse de la logique de l'événement déjà évoquée. Ce sont toutefois des ressources proches de celles du conceit métaphysique que Niedecker mobilise lorsqu'il s'agit pour elle d'aborder le contexte immédiat de la Guerre Froide, dans lequel la pratique de la « condenserie » permet de déplacer le conflit sur la scène de l'agon textuel. La stratégie de déplacement qui opère dans les poèmes consacrés à la menace d' «oblitération" nucléaire permet également à Niedecker de régler tel différend littéraire et genré qui l'oppose à Zukofsky, et par là, d'interroger l'instance de l'Autre symbolique conceptualisée par Lacan, Autre qui, en même temps qu'il est sommé d'autoriser ou d'invalider certains choix lexicaux, expose également sa propre incapacité à garantir les énoncés et l'être même du sujet. 


\section{INDEX}

Keywords: condensation, displacement, Niedecker Lorine, condensery, Freud Sigmund, wit, syllepsis, economy

Mots-clés: condensation, déplacement, Niedecker Lorine, condenserie, Freud Sigmund, trait d'esprit, syllepse, économie

\section{AUTHOR}

\section{AXEL NESME}

Professor of American Literature, University of Lyon. Axel Nesme specializes in twentiethcentury American poetry and literary theory. His publications include articles on Wallace Stevens, Elizabeth Bishop, Walt Whitman, as well as a book-length study on American elegies entitled L'Autre sans visage (Honoré Champion, 2012). Contact: axel.nesme [at] univ-lyon2.fr 